\title{
Japanese Urban Development and the Railway Network, 1880-1980
}

\author{
Toru TANIUCHI*
}

\begin{abstract}
This study sets out to examine the structural and spatial changes in the relative status of the hundred largest urban centers in Japan from 1880 to 1980 in relation to the development of railway network; it charts the structural changes by means of rank-size curves and rank correlation coefficients, and the spatial changes by means of descriptive maps.

We can date the structural and spatial patterns of the present urban system as well as the geographical features of the present transport network back to 1908 , to a large extent to 1880 , even to the era before 1868. Urban development after 1880 was not the emergence of a brand new system but rather a process of readjustment of the already existing urban system.

The major changes after 1880 were the increasing metropolitan dominance and the relative growth of the centers along the main spine of the Pacific coast. There were greater structural changes in the periods before 1908, in contrast to the periods of structural stability, with further reinforcement after 1908 of the dominance of the metropolitan areas and the main spine.

Although the periods before 1908 are characterized by the major development of the railway network, it is difficult to establish a clear spatial relationship between the newly opened lines and the urban development beside them. The railway network rather reinforced metropolitan dominance and the further growth of the centers along the main spine. If we are allowed to extend the definitions of a metropolis and main spine, to take into account of the more rapid growth of the regional centers than the three metropolitan areas after the mid-1970s and the development of the new transport networks of super highways, Shinkansen lines and air services after the 1960s, the basic trend will not change in the near future.
\end{abstract}

This paper offers a general picture of urban development in Japan from 1880 to 1980 , in specific relation to the development of the railway network. ${ }^{1)} \quad$ Urban development is identified by the changing status and distributional patterns of the hundred largest urban centers within the four main islands, in terms of urban population $^{2)}$ and railway passenger revenue. ${ }^{3)}$

In the first part of the paper, structural changes in the urban system are examined by means of rank-size curves and rank correlation coefficients. In the second part, spatial changes in the geographical distribution of the urban centers are discussed by means of descriptive maps.

\section{Structural changes}

\section{Metropolitan dominance}

Figure 1 and Table 1 summarize the urban population growth from 1880 to 1980 . The total urban population is divided into two categories, metropolitan and other urban. The metropolitan population is defined as the urban population in the three metropolitan areas;

Table 1. Urban population, $1880-1980$ (million).

\begin{tabular}{ccccc}
\hline \hline Year & $\begin{array}{c}\text { Metro- } \\
\text { politan }\end{array}$ & $\begin{array}{c}\text { Other } \\
\text { urban }\end{array}$ & $\begin{array}{c}\text { Total } \\
\text { urban }\end{array}$ & $\begin{array}{l}\text { National } \\
\text { population }\end{array}$ \\
\hline 1880 & 2.2 & 2.4 & 4.6 & 36.6 \\
1893 & 3.5 & 3.5 & 7.1 & 40.9 \\
1908 & 6.3 & 7.1 & 13.5 & 48.0 \\
1920 & 8.6 & 8.2 & 16.8 & 56.0 \\
1935 & 15.4 & 10.2 & 25.6 & 69.3 \\
1960 & 23.0 & 17.8 & 40.8 & 94.3 \\
$1980 *$ & 42.0 & 27.9 & 69.9 & 117.1 \\
\hline * Okinawa is included. (If Okinawa is excluded, other \\
urban 27.3, total urban 69.3, national population 116.0.)
\end{tabular}

\footnotetext{
* Faculty of Letters, Hokkaido University. Sapporo 060, Japan.
} 


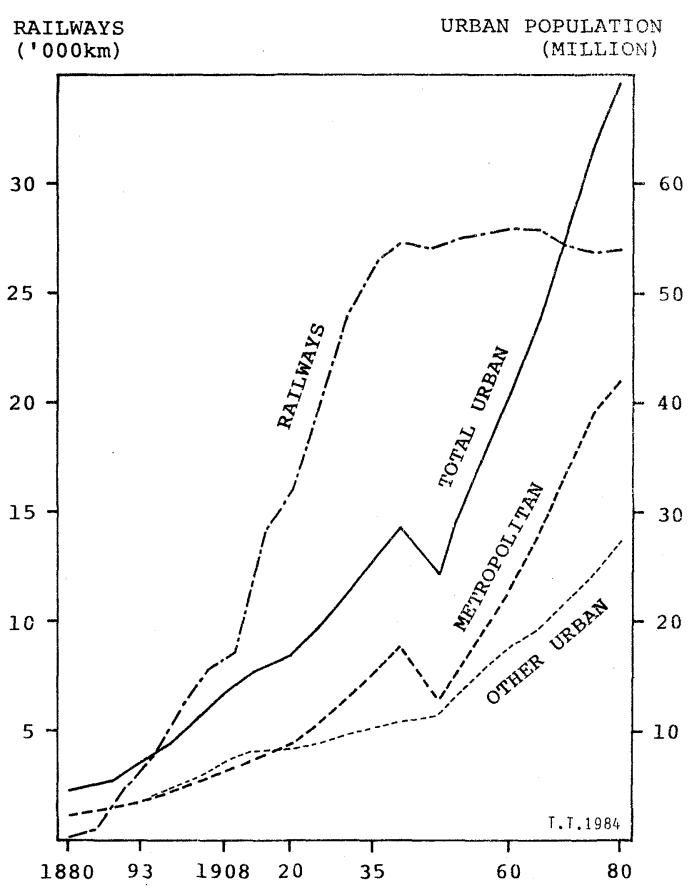

Figure 1. Urban population and railway routekilometers, 1880-1980.

the areas within $60 \mathrm{~km}, 50 \mathrm{~km}$ and $40 \mathrm{~km}$ radius of Tokyo, Osaka and Nagoya, respectively.

The metropolitan population already occupied nearly half the total urban population in the earlier days. This original metropolitan dominance has been further reinforced since 1908, by growing much faster than the rest of the urban population, by absorbing a larger part of the increase in the total urban population, except for a sharp drop caused by World War II.

\section{Changes in rank-size curves}

The metropolitan dominance, especially of the two giant metropolitan areas of Tokyo and Osaka, is also shown in Figure 2. Another feature of Figure 2 is that the curves for the other urban centers are almost straight and parallel with each other, although there appear some apparent changes in the shape before 1908 and after 1960. The findings from Figure 2 suggest that, if we ignore the changing status of individual centers, the overall structural patterns have been almost stable since 1908,

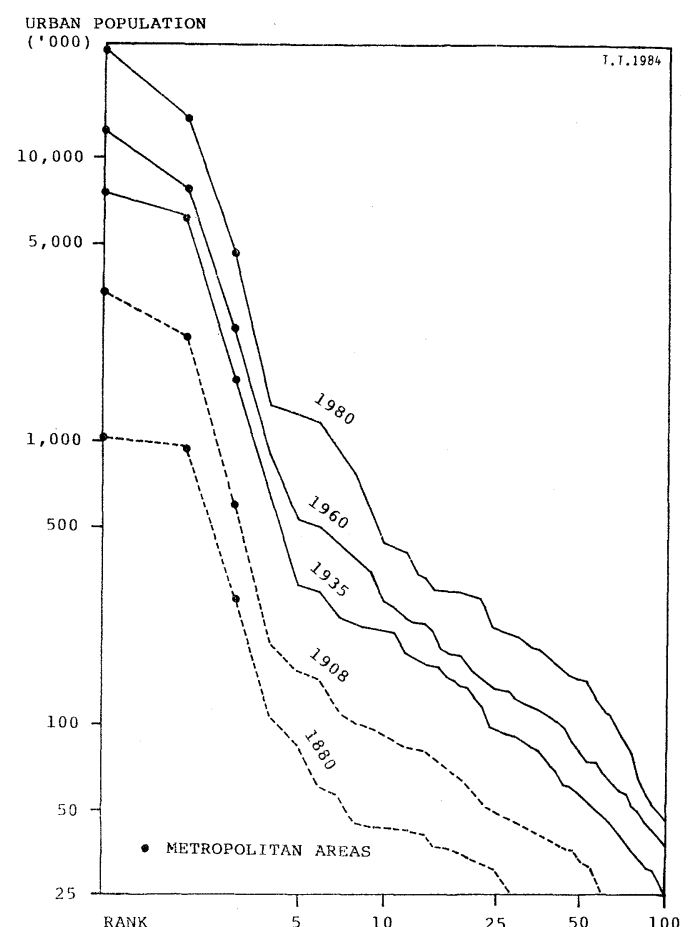

Figure 2. Rank-size curves of urban population, 1880-1980.

with some changes after 1960 which will be discussed more fully later.

We have so far identified the metropolitan population as the urban population of the three metropolitan areas defined to reflect the actual urban agglomerations in 1980 (let us call this the 1980 definition), and we have applied the same definition to the earlier dates to keep technical consistency. It is more realistic, however, to apply another definition (let us call it the 1935 definition), where the conventional six major cities ${ }^{4)}$ and other urban centers located within the three metropolitan areas are now identified as separate centers, ${ }^{5)}$ for detailed discussions for the periods before 1935 .

Figures 3 and 4 are rank-size curves for the earlier dates in terms of urban population and railway passenger revenue, by the 1935 definition. In Figure 3, the rank-size curve for 1880 is more straight than the one in Figure 2, filling the gap with the centers which were consolidated into the metropolitan areas by the 1980 definition. The curve for 1893 is also straight and parallel with the one for 1880. The dominance of six major cities 


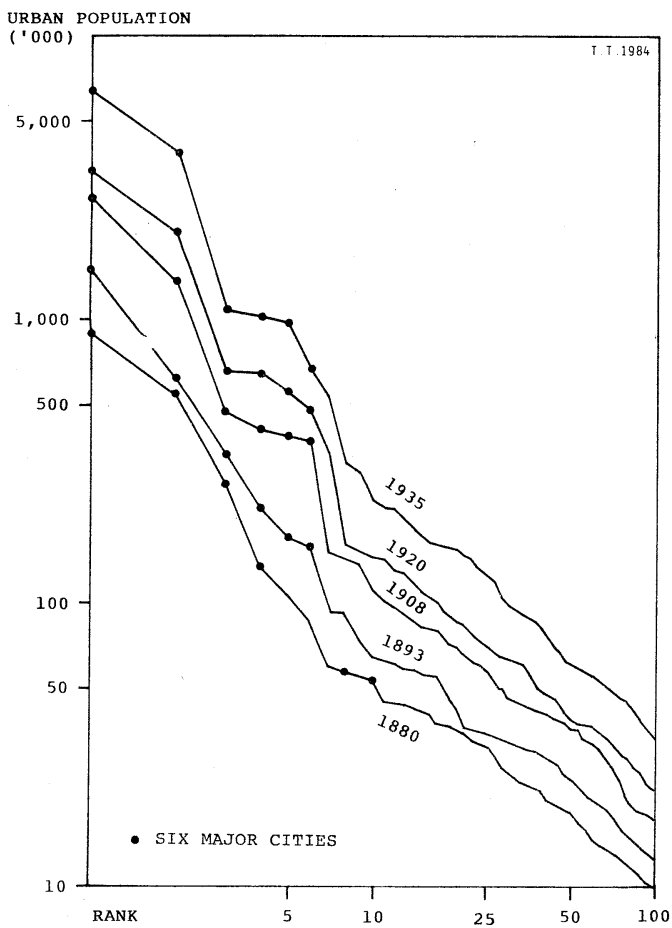

Figure 3. Rank-size curves of urban population, 1880-1935.

was established by 1893 with the growth of the two modern port cities, Yokohama and Kobe. By 1908, a major change had occurred because of the growth of the six major cities and this new pattern of metropolitan dominance was maintained until 1935.

Rank-size curves of railway passenger revenue for the centers within the integrated railway networks ${ }^{6}$ ) in Figure 4 are also parallel with each other, although the counterpart of the major change in the pattern caused by the metropolitan growth between 1893 and 1908 in Figure 3 now appears rather clearly in the period from 1908 to 1920 in Figure 4. This ap parent time-lag may suggest that changes in railway activity are more likely to follow population growth, not vice versa.

\section{Changes in rank correlation coefficients}

A rank correlation coefficient is calculated for each group of urban centers classified by rank for each period, employing the rankings at the beginning and at the end of the period. ${ }^{7}$ It is assumed that a lower rank correlation coef-

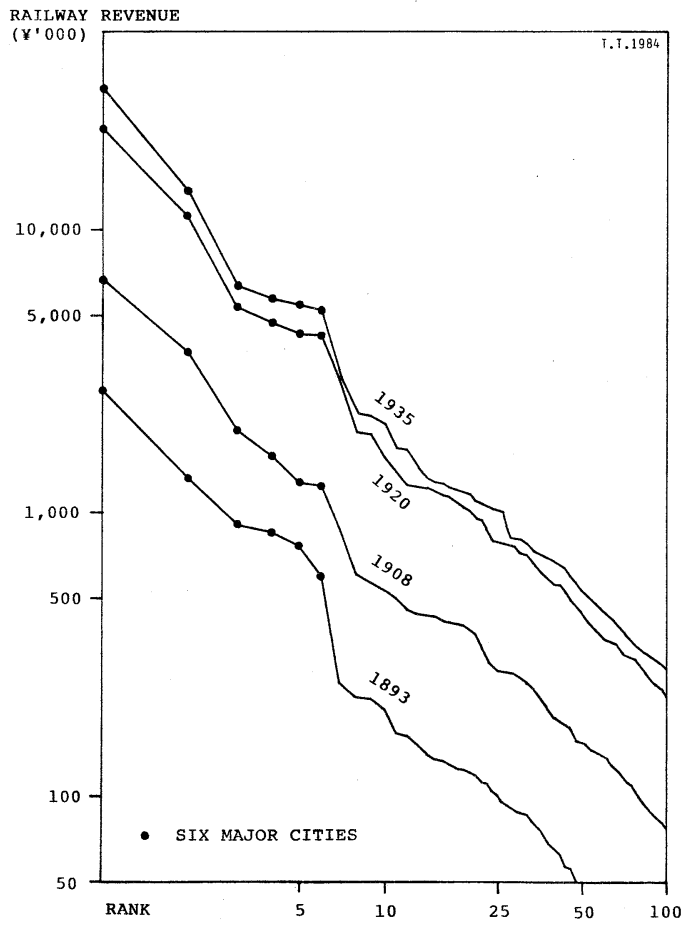

Figure 4. Rank-size curves of railway passenger revenue at 1935 fare level, 1893-1935.

ficient means a certain structural change in the urban system, and a higher coefficient suggests stability of the system. The results are summarized in Tables 2 and 3.

An inter-period comparison of the rank correlation coefficients of urban population in Table 2 reveals that the year 1908 was a turning point; this is consistent with the results from the rank-size curves in the previous section. The most volatile period with the lowest coefficients was the 1893-1908 period, in contrast to the stable periods with higher coefficients

Table 2. Rank correlation coefficients of urban population, $1880-1980$.

\begin{tabular}{|c|c|c|c|c|c|}
\hline \multirow{2}{*}{ Period } & \multicolumn{3}{|c|}{ Rank } & \multicolumn{2}{|c|}{$\begin{array}{c}\text { Prefectural } \\
\text { capitals }\end{array}$} \\
\hline & $1-25$ & $1-50$ & $1-100$ & $1-20$ & All \\
\hline $1880-1893$ & 0.82 & 0.78 & 0.82 & 0.87 & 0.93 \\
\hline $1893-1908$ & 0.57 & 0.60 & 0.78 & 0.81 & 0.90 \\
\hline $1908-1920$ & 0.92 & 0.91 & 0.89 & 0.94 & 0.94 \\
\hline $1920-1935$ & 0.95 & 0.97 & 0.96 & 0.95 & 0.98 \\
\hline $1935-1960$ & 0.92 & 0.89 & 0.95 & 0.95 & 0.98 \\
\hline $1960-1980$ & 0.87 & 0.74 & 0.90 & 0.96 & 0.96 \\
\hline
\end{tabular}


Table 3. Rank correlation coefficients of railway passenger revenue, 1893-1935.

\begin{tabular}{ccccccc}
\hline \multirow{2}{*}{ Period } & \multicolumn{3}{c}{ Rank } & & \multicolumn{2}{c}{$\begin{array}{c}\text { Prefectural } \\
\text { capitals }\end{array}$} \\
\cline { 2 - 4 } & $1-25$ & $1-50$ & $1-100$ & & $1-20$ & All \\
\hline $1893-1908$ & 0.53 & 0.76 & & & 0.83 & \\
$1908-1920$ & 0.89 & 0.94 & 0.92 & & 0.93 & 0.95 \\
$1920-1935$ & 0.92 & 0.90 & 0.93 & & 0.96 & 0.94 \\
\hline
\end{tabular}

Table 4. Rank correlation coefficients between population and railway rankings, 1893-1935.

\begin{tabular}{|c|c|c|c|c|c|}
\hline \multirow{2}{*}{ Year } & \multicolumn{3}{|c|}{ Rank } & \multicolumn{2}{|c|}{$\begin{array}{l}\text { Prefectural } \\
\text { capitals }\end{array}$} \\
\hline & $1-25$ & $1-50$ & $1-100$ & $1-20$ & All \\
\hline 1893 & 0.57 & 0.59 & & 0.78 & \\
\hline 1908 & 0.63 & 0.70 & $0.80 *$ & 0.73 & 0.76 \\
\hline 1920 & 0.73 & 0.77 & 0.80 & 0.85 & 0.89 \\
\hline 1935 & 0.75 & 0.78 & 0.75 & 0.94 & 0.86 \\
\hline
\end{tabular}

*1-75

between 1908 and 1960, and, to a less extent, to the periods of $1880-1893$ and $1960-1980$. The coefficients for the prefectural capitals are generally higher, suggesting overall stability of the system and the relative importance of changes in the other kinds of urban center: industrial towns, port towns, smaller towns, etc.

Table 3 shows rank correlation coefficients of railway passenger revenue from 1893 to 1935 . The centers studied are confined to those which were already within the integrated railway network at the beginning of each period; other centers along the isolated lines or ones not yet connected at the beginning of the period are excluded for technical reasons. During 18931908 , even within the already existing railway network, there was a considerable change, in contrast to the remarkable stability after 1908; this supports the results in Table 2 . If we include centers newly opened, the above contrast would be much more striking, because fewer major centers were newly connected by the railway network after 1908 .

Table 4 shows rank correlation coefficients between population and railway rankings ${ }^{8)}$ from 1893 to 1935 . The centers studied are also confined to those within the integrated railway network at each date. The coefficients are not so high as those in Tables 2 and 3 , reflecting industrial towns with higher population rankings, and centers near the metropolises as well as tourist oriented centers with higher railway rankings in nature. However, progressive improvement from very low coefficients in 1893 to fairly high and stable ones after 1920 as well as higher coefficients for the prefectual capitals suggest a growing relationship between the two sets of rankings.

At the close of the first part, we can tentatively conclude that urban development after 1880 was not the emergence of a brand new urban system but rather a process of readjustment of the already existing urban system with increasing metropolitan dominance and a contrast between changes and stability before and after 1908.

\section{Spatial changes}

\section{Long-term changes}

Figure 5 shows long-term changes in the geographical distribution of the urban centers from 1880 to 1980 . Although the urban centers are identified by different definitions, the numbers of larger centers (white circles) and smaller centers (black ones) outside the three metroploitan areas by the 1980 definition are adjusted to include the same number of centers at each date: 20 larger centers and 60 smaller centers.

The distributional pattern of the urban centers in 1880 can be regarded as a legacy of the Tokugawa era before 1868. ${ }^{9)}$ The 26 largest centers in 1880 (all the white circles) consisted of the three traditional metropolises (Tokyo, Osaka and Kyoto), 19 former major castle towns that include the next six largest centers with the name on the map and that were among the largest castle towns, as well as four port towns of which only Yokohama and Kobe can be regarded as newly developed centers. In short, 24 of the 26 centers were traditional major centers, and most of the other smaller centers in 1880 were also castle towns, port towns or other important centers before 1868.

Apart from the growth of the three metropolitan areas, the most striking spatial change from 1880 to 1980 was a reduction in the 


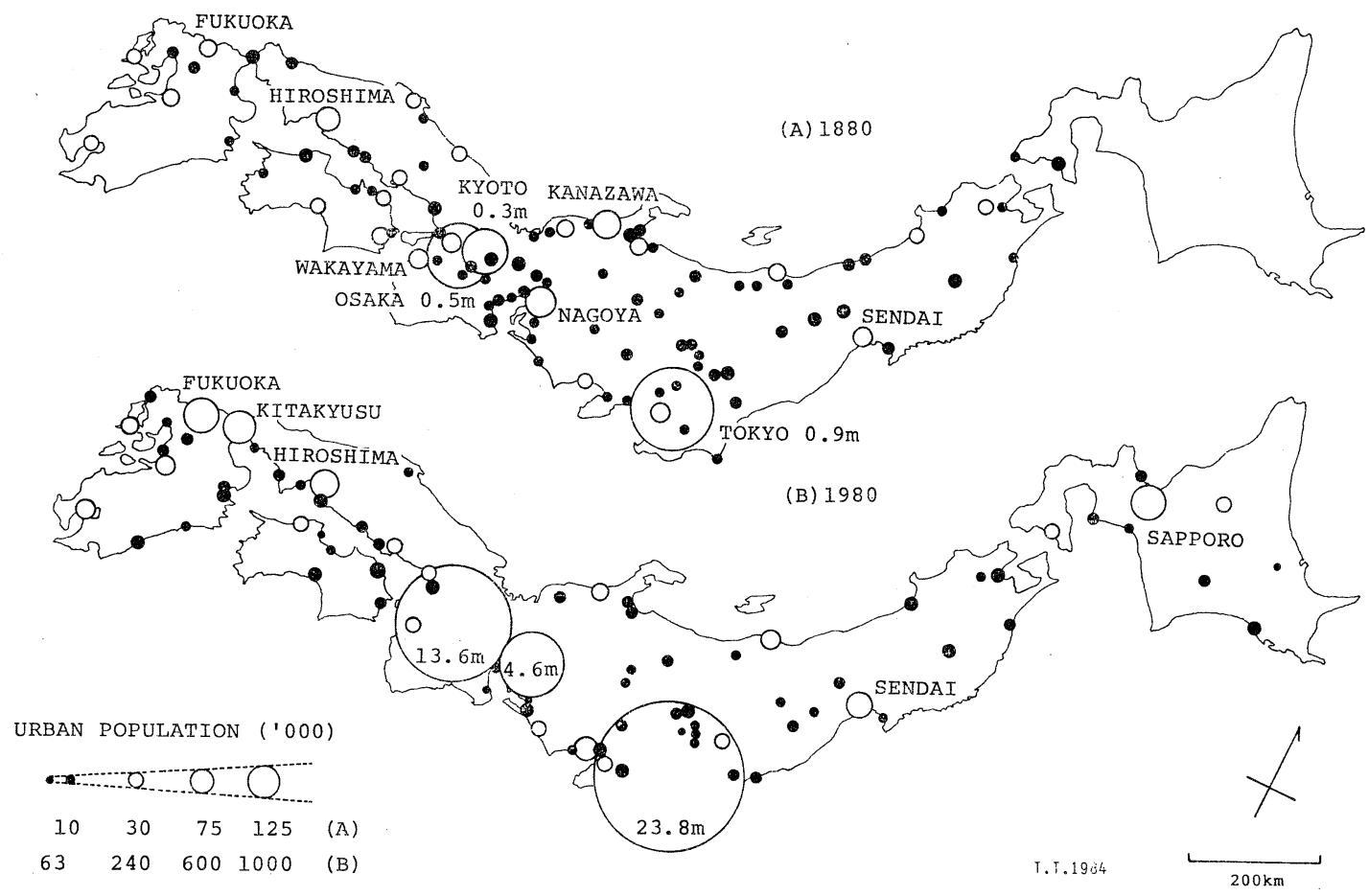

Figure 5. Distribution of urban centers in 1880 and 1980.

number of the major urban centers along the Japan Sea coast area of Honshu; the number of larger centers (white circles) fell from eight to only two and smaller centers (black ones) from 22 to 12, in contrast to the gains in the Pacific coast area of Honshu as well as in Hokkaido. ${ }^{10)}$

\section{Spatial changes before 1935}

Figure 6 and Figure 7 show the hundred largest urban centers classified by rank at the end of each period and by relative growth rates during the period ${ }^{11)}$ in terms of urban population or railway passenger revenue, as well as the railway network at the end of the period.

Although the first railway was opened between Tokyo and Yokohama in 1872, only two more short lines from Otsu (east of Kyoto) to Kobe and from Otaru to Sapporo were opened by 1880 . In 1880-1893, two major lines along the main spine, ${ }^{12)}$ the Tokaido line from Tokyo to Kobe and the Tohoku line from Tokyo to Aomori (the northern end of Honshu) were opened as well as other extensions from Kobe to the west and from Tokyo to the northwest as well as in Kyushu and Hokkaido. Growing centers in terms of urban population in this period (Figure 6-A) were mainly confined to Tokyo, Nagoya, four port towns including Yokohama and Kobe, and smaller centers along the new line to the northwest of Tokyo, where the growing silk industry had an important relation with the early extension of the railway in order to link it with the new export outlet, Yokohama. Most of the other centers, including those along the new lines, failed to grow or even declined.

The next period (1893-1908) was a period of major construction. The Railway Construction Act was a long-term master plan in force by 1892 and major lines were eventually nationalized in 1906 and 1907, leading to the establishment of the national railway system both geographically and institutionally. The two periods from 1880 to 1908 correspond to the first stage of railway construction characterized by the construction of trunk lines, defined by Aoki (1979).

As is shown in Figure 6-B, not only was the line along the main spine by the extension of 


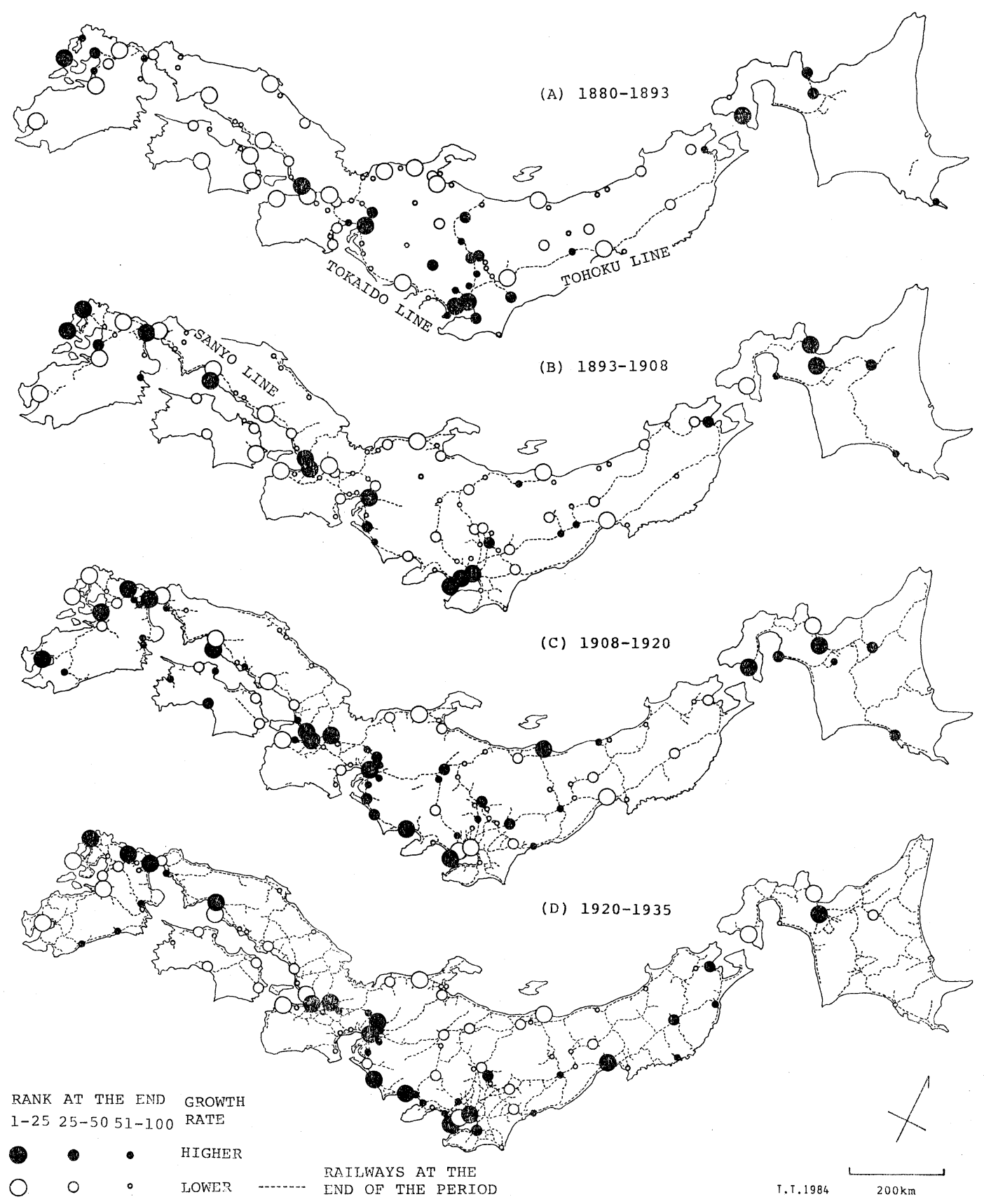

Figure 6. Changing status by urban population, 1880-1935.

the Sanyo line to Shimonoseki (the western end of Honshu) completed, but also more major lines were opened in the Japan Sea coast area, so that most of the 50 largest centers in terms of population were connected by the railway network by the end of the period. Growing centers in terms of urban population in this period are mainly confined to the metropolitan areas, a few industrial towns and port towns, including rapidly growing naval base towns, within the Tokyo - Northern Kyushu corridor along the Tokaido and Sanyo lines as well as 


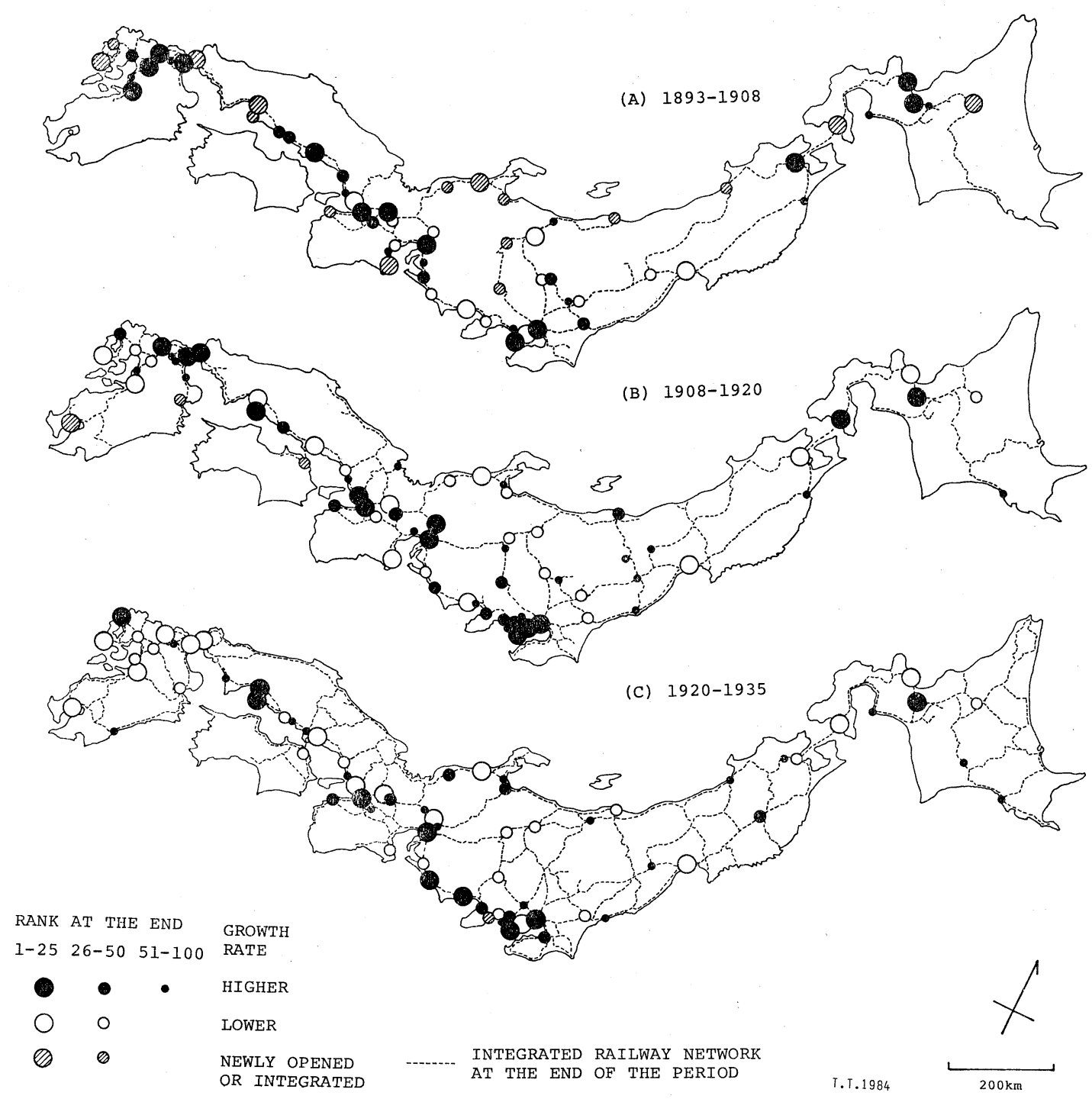

Figure 7. Changing status by railway passenger revenue, 1893-1935.

in Hokkaido. Many other centers including those along the new lines failed to grow.

In Figure 7-A, we can see that more centers of greater growth in terms of railway passenger revenue are to be found along the Tokyonorthern Kyushu corridor than the centers of growth in terms of population shown in Figure 6 -B. This suggests that growth of railway activity does not necessarily lead to urban growth in terms of population, implying a certain backwash effect. This can be also applied to the centers along the new lines.

In 1908-1920, the railway network was extended much further to include the new lines stimulated by the Light Railway Act of 1910 and the Light Railway Subsidy Act of 1911. This period is called by Aокі (1979) the light railway stage. By the end of the period, most of the hundred largest centers in terms of urban population were brought into the railway network, and only a few larger centers in terms of railway passenger revenue remained to be integrated. Although many growing centers may be found both in Figure $6-\mathrm{C}$ and Figure 7-B, the most striking feature during this period is that the area along the Tokaido 
line between Tokyo and Osaka emerged as the corridor of major growth.

The period from 1920 to 1935 is characterized by further construction of many branch lines and bridge lines stimulated by the major amendment of the Railway Construction Act in 1922 for easier construction by the government, with more political involvement in the decision-making. Many lines built in this period are heavy deficit lines at present. This period is the third stage as defined by AokI (1979). By the end of the period, a highly articulated, even saturated, network reached its mature stage, one almost identical to the present network (Figure 6-D, see also Figure 1).

In Figure $6-\mathrm{D}$, most of the growing centers in terms of urban population can be seen to be confined to the areas along the main spine, including the Tohoku line and northern Kyushu, while no centers of growth are found along the Japan Sea coast and in Shikoku. Many larger growing centers along the Tokaido corridor are as striking as in the previous period. In Figure 7-C, we can see that although many larger growing centers in terms of railway passenger revenue are found along the Tokaido corridor, some growth of revenue can be found in the Japan Sea coast area, which failed to grow in terms of population. This suggests again the backwash effect as in 1893-1908.

The spatial changes from 1880 to 1935 are summarized as the continuous growth of the centers along the main spine, especially the metropolitan areas and other centers in the Tokaido corridor, while most of the other centers failed to grow or rather declined, especially the larger centers along the Japan Sea coast. Although the geographical extension of the railway network was striking, especially in 1880-1908, centralizing forces were stronger than decentralizing forces, resulting in the spatial restructuring of the distribution of the urban centers.

\section{Spatial changes after 1935}

Figure 8 shows further spatial changes in terms of urban population from 1935 to 1980 . The urban centers are now identified by the 1980 definition. In 1935-1960, decentralization away from the metropolitan areas to the

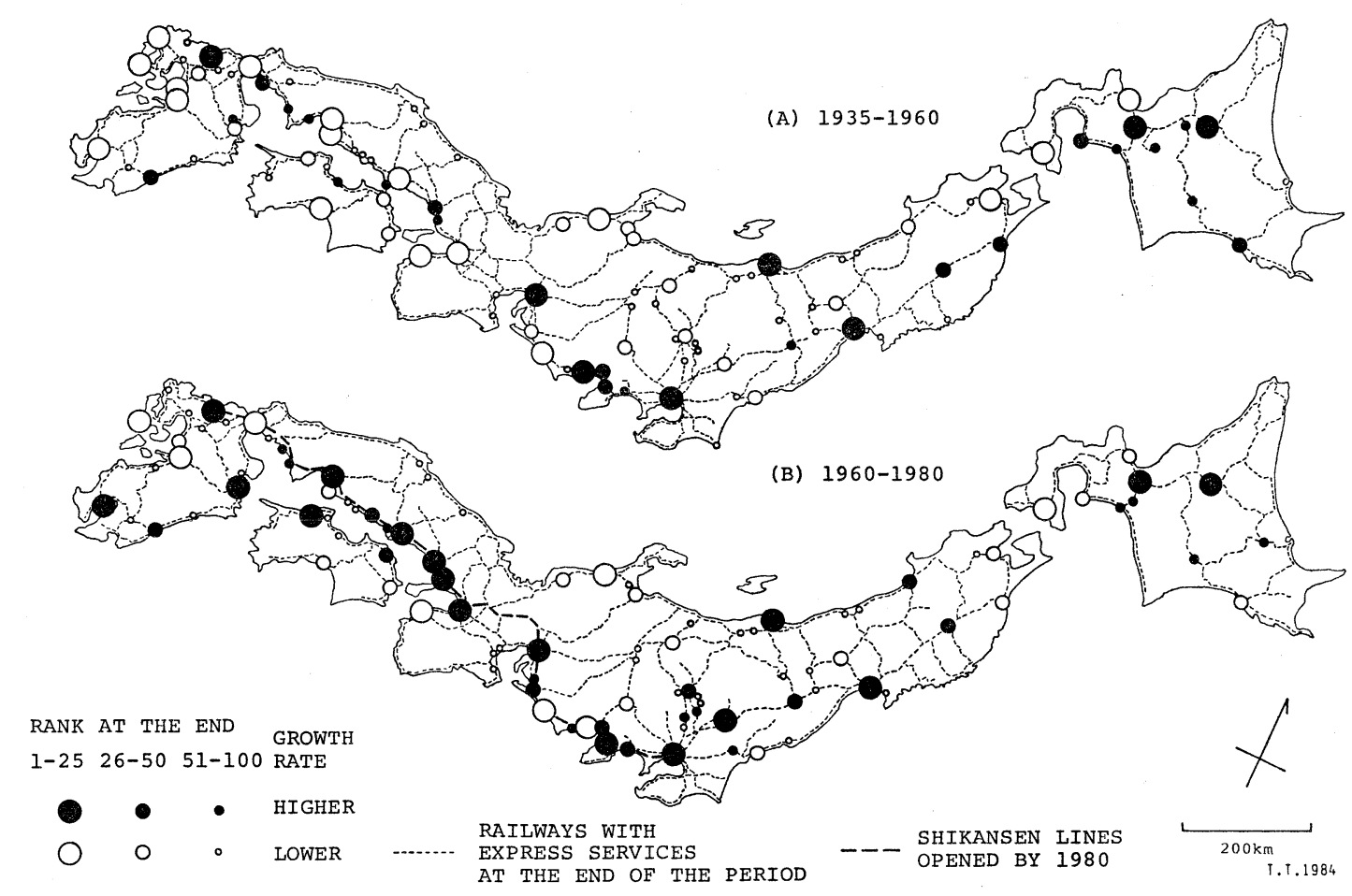

Figure 8. Changing status by urban population, 1935-1980. 
other centers caused by World War II were almost cancelled out by the post-war reconstruction and further growth in the late 1940s and in the 1950s. Although the centralizing trend towards the main spine is less striking, more centers of growth are found there. The centralizing trend to the main spine was much more reinforced in 1960-1980, especially by the growth of the larger centers along the Sanyo line. The structural changes in this period noted by the less straight curve in Figure 2 and the lower rank correlation coefficients in Table 2 than for the previous periods are mainly due to the rapid growth of the centers along the main spine as well as in Hokkaido.

Although there were only very minor geographical changes in the railway network, the construction of the Shinkansen (a new rapid and frequent system) along the Tokaido and Sanyo lines from Tokyo to Fukuoka in northern Kyushu was the main development of this period. It would, however, be too simple to attribute the growth of the centers along the Tokyo-Fukuoka corridor to the commencement of the Shinkansen services, because the Shinkansen system was constructed to cope with the rapidly growing traffic demand caused by the urban and industrial development of the area which was too heavy a burden to be carried by the conventional system (HARADA, 1977).

Other than the Shinkansen system, there have been new developments in the transport network since 1960; super highways, longdistance car ferries and air services, which are briefly discussed in the next section.

\section{Transport networks, past and present}

Figure 9 summarizes selected transport networks before 1868 and at present. ${ }^{13)}$ By comparing these maps, we can find common features in the geographical patterns of the transport networks in the past and at present.

In the Tokugawa period before 1868, under the limited technological conditions of an era of walking travel and coastal sailing, a fairly developed transport network had already been established. Primary and secondary highways with road-side stations for accommodation and other services were maintained under the supervision of the Tokugawa central government at Edo (Tokyo), while other roads (not shown on the map) were also maintained by other local rulers. The route with the highest priority and with the heaviest traffic was the one from Tokyo to Kyoto and Osaka; this was called the Tokaido and gave its name to the most important and the busiest railway line opened in 1889, as well as the first Shinkansen line on the same route opened in 1964 . The major highway network before 1868, which consisted of the most important links between the metropolitan areas and the extensions to the north and to the west as well as the branches to the Japan Sea coast, can be regarded as a prototype of the modern transport networks.

Among the coastal sailing routes in operation before 1868, the routes along the Japan Sea coast were of special importance, supporting many centers there. The relative decline of many of these centers during the course of railway development may be at least partly related to the changes in the relative status of the area in the national transport network from being the former main corridor to becoming separate dead ends of branch lines from the new corridor along the Pacific coast. Although the shipping routes along the Japan Sea coast were partly resumed as car ferry routes after 1960 , they are different in nature from those of the past, because they are mainly for direct links between Honshu (especially the Osaka metropolitan area) and Hokkaido, while all the other car ferry routes pass along the Pacific coast.

Only a few words may be necessary to point out some common features in the super highway network and the railway network with frequent limited express services. ${ }^{14)}$ If we select busier railway links with 20 services or more in Figure 9-C, consisting of the three Shinkansen links from Tokyo to Fukuoka, Morioka and Niigata ${ }^{15)}$ and other comparable sections of conventional lines, we can find a pattern similar to the super highway network and to the railway network in 1908, and even to the highway network before 1868 .

The car ferry routes and the air routes share common features as direct links from Tokyo and Osaka to centers in Hokkaido, Kyushu and Shikoku. The patterns are apparently 


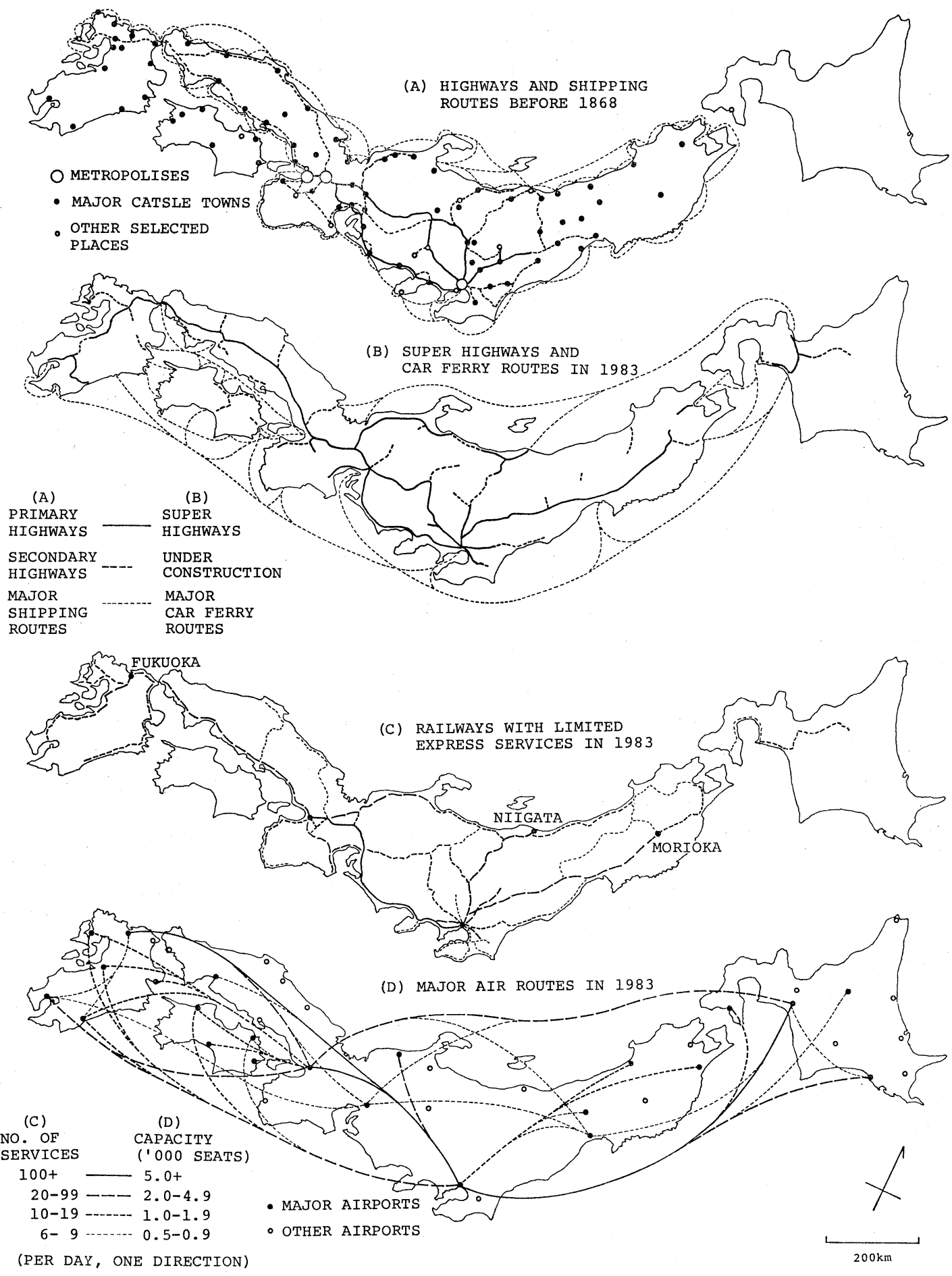

Figure 9. Transport networks before 1868 and in 1983. 
different from the networks of super highways and railways, because of their complementary nature. However, the fact that the most important air links are those on the extended spines from Sapporo through Tokyo and Osaka to Fukuoka is worth noting. If we consolidate these network patterns into one, a nationwide spine would emerge.

Since the mid-1970s, the population of the three metropolitan areas has grown more slowly than that of other urban populations and several larger centers, such as Sapporo, Sendai, Hiroshima and Fukuoka, are growing more rapidly. ${ }^{16)}$ Although it seems to be too early to discuss this new trend within the historical framework laid down for this study, it would be consistent with the present transport network to extrapolate that metropolitan dominance is going to be shared with these major regional centers along the extended national spine, skipping over or by-passing other centers. It would be a matter of definition whether we call it centralization along the main spine or decentralization away from the three metropolitan areas.

\section{Concluding remarks}

One of the major findings from the study is that we can date the long-term stability of the urban system and the transport network back to 1880 , or even to the era before 1868 .

Within that long-term stability, a contrast between relative structural changes before 1908 and stability after 1908 can be identified. Although we are tempted to attribute this contrast to the process of railway development, especially the major development before 1908, it is difficult to establish a clear spatial relationship in the sense that an emerging railway network stimulated and extended urban growth along the newly opened lines.

The major finding of this study suggests that the railway network rather stimulated and reinforced the metropolitan dominance and the growth of the centers along the main spine. If we are allowed to extend the definitions of a metropolis and main spine, to take into account of the more rapid growth of the regional centers than the three metropolitan areas after the mid-1970s and the development of the new transport networks of super highways, Shinkansen lines and air services after the 1960s, the basic trend will not change in the near future.

(Received June 1, 1984)

(Accepted July 26, 1984)

\section{Notes}

1) This paper is a revised and extended version of the author's earlier work (T $T_{\text {ANIUCHI }}, 1982$ ).

2) Estimated and arranged by the author and based upon data from Bureau of Statistics (1921, 1961 and 1983) and their earlier issues, as well as Отомо (1979) and Japanese Army, the General Staff Office (1880).

3) Estimated and arranged by the author and based upon data from Ministry of Railways (1936) and its earlier issues, as well as Bureau of Statistics (1894). Other historical facts on the railway development are based upon Japan National Railways (1969-1974), ANDO (1979) and HARADA (1977).

4) Tokyo, Yokohama, Nagoya, Kyoto, Osaka and Kobe. Population data for Tokyo and Osaka by the 1935 definition includes other urban population within $30 \mathrm{~km}$ and $20 \mathrm{~km}$ radius, respectively.

5) Some centers outside the metropolitan areas which are identified as conurbations by the 1980 definition are in most cases identified as separate centers. Kitakyushu is regarded as a conurbation even by the 1935 definition and includes Shimonoseki by the 1980 definition.

6) Isolated lines, minor branch lines, intra-metropolitan lines and most of the private lines are excluded, but we include isolated systems in Hokkaido and Kyushu in 1893.

7) Rank 1-n means a group of urban centers which fall into this category either at the beginning or at the end of the period. Coefficients are calculated by the relative rankings within the group.

8) Rank 1-n means a group of urban centers which fall into this category either in terms of population or railway rankings.

9) The relationship between the old urban system before 1868 and the modern urban system is more fully discussed by Fusioka (1980),

KornhaUSER (1976), H. TaNABE (1979) and K. $\mathrm{T}_{\text {ANABE }}$ and $\mathrm{H}$. TANABE (1982).

10) Urban development and railway development almost coincided in Hokkaido before 1920, but much less so after 1920 (T $\mathrm{T}_{\text {ANIUCHI }}, 1979$ ).

11) For urban population, higher growth rates mean those higher than the growth rate of the total urban population in each period. For railway 
passenger revenue, higher growth rates mean those higher than the growth rate of the total of the group of rank 1-50 in 1893-1908 and of the total of the group of rank 1-100 in each period after 1908 .

12) The main spine is defined in this paper as the line from Aomori to Fukuoka along the Tohoku, Tokaido and Sanyo lines.

13) Compiled by the author and based upon historical atlases, highway atlases and timetables.

14) Limited express services generally offer a higher standard and longer-distance services than ordinary express services.

15) Two Shinkansen lines from Tokyo to Morioka and Niigata were opened in 1982.

16) More fully discussed by $\mathrm{A}_{\mathrm{BE}}$ (1982), GLICKMAN (1979) and Y YMAGUCHI (1983).

\section{References}

AbE, T. (1982): Toshi kaiso no saikin no henka (Recent changes in the urban hierarchy in Japan). In TANABE, K. (ed.): Nihon no toshi shisutemu: chirigakuteki kenkyu (Urban system in Japan: a geographical study). Kokon Shoin, Tokyo, 70-82.

Ando, Y. (ed.) (1979): Kindai Nihon keizaishi yoran (Handbook of the economic history of modern Japan). second edition, University of Tokyo Press, Tokyo, $233 \mathrm{p}$.

AокI, E. (1979): Chiiki shakai kava mita tetsudo kensetsu (Railway construction and regional communities). United Nations University, Tokyo, $24 \mathrm{p}$.

Bureau of Statistics (1894): Nihon Teikoku dai 13 tokei nenkan (The 13th statistical yearbook of the Japanese Empire).

Bureau of Statistics (1921): Nihon Teikoku dai 39 tokei nenkan (The 39th statistical yearbook of the Japanese Empire).

Bureau of Statistics (1961): Showa 35 nen kokusei chosa hokoku: jinko sosu (1960 Population census of Japan: total population).

Bureau of Statistics (1983): Showa 55 nen kokusei chosa hokoku: wagakuni no jinko shuchu chiku (1980 Population census of Japan: densely inhabited districts).

Fujroka, K. (1980): The changing face of Japanese jokamachi (castle towns) since the Meiji period. In The Association of Japanese Geographers (ed.): Geography of Japan. Teikoku-Shoin, Tokyo, 146-
160.

Glickman, N.J. (1979): The growth and management of the Japanese urban system. Academic Press, New York, 370 p.

HARADA, K. (1977): Tetsudo no kataru Nihon no kindai (Railway development in modern Japan). Soshiete, Tokyo, $265 \mathrm{p}$.

Japan National Railways (1969-1974): Nihon Kokuyu Tetsudo hyakunen shi (The hundred years' history of the Japan National Railways). Tokyo, 19 vols.

Japanese Army, the General Staff Office (1880): Kyobu seihyo (Statistics by settlement). Tokyo, 2 vols., reprinted in 1978 .

KoRNHAUSER, D. (1976): Urban Japan: Its foundation and growth. Longman, London, $180 \mathrm{p}$.

Ministry of Railways (1936): Showa 10 nendo tetsudo tokei shiryo (Railway statistics 1935).

Отомо, A. (1979): Nihon toshi jinko bunpuron (Geographical distribution of urban population in Japan). Taimeido, Tokyo, $242 \mathrm{p}$.

TANABE, H. (1979): L'Evolution du reseau urbain au Japon. Tokyo Daigaku Jinbun Kagakuka Kiyo (Proceedings of the Department of Humanities, University of Tokyo), 69, 16-29.

$\mathrm{T}_{\mathrm{ANABE}}, \mathrm{K}$. and TANABE, H. (1982): Toshi shisutemu no hatten dankai (Stages of development in the Japanese urban system). In T TANAB, $K$. (ed.): Nihon no toshi shisutemu: chirigakuteki kenkyu (Urban system in Japan: a geographical study). Kokon-Shoin, Tokyo, 37-57.

TANiUchi, T. (1979): Development of the transport network and the urban system in Hokkaido, 1879 1975. Hokkaido Daigaku Jinbunkagaku Ronshu (Reports on Cultural Science, Hokkaido University), 16, 1-22.

TANIUCHI, T. (1982): Tetsudomo no hattatsu to toshi shisutemu no henyo, 1879-1978 nen (Changes in urban system through the development of railway network, 1879-1978). In TANABE, K. (ed.): Nihon no toshi shisutemu: chirigakuteki kenkyu (Urban system in Japan: a geographical study). KokonShoin, Tokyo, 70-82.

Yamaguchi, T. (1983): Population redistribution of Japan, within the context of the national settlement system. Tokyo Daigaku Jinbun Kagakuka Kiyo (Proceedings of the Department of Humanities, University of Tokyo), 78, 1-18. 


\section{日本における都市の発達と鉄道網，1880年-1980年}

谷内達*

日本の主要都市の発達を鉄道網と関連させて概観する ために，1880年-1980年を 6 期に分け，各期における上 位 100 都市の相対的地位の変化を構造的および空間的に 比較検討した。すなわち都市人口および鉄道旅客収入額 を指標に用いて，順位規模曲線および順位相関係数によ り構造的変化を検討し, 順位・成長率による区分を加え た都市分布図により空間的変化を検討した。

現在の都市システムの構造的・空間的特徵叔よび交通 網の骨格は 1908 年当時のものと大差なく, 基本的には 1880 年, さらには 1868 年以前にまでさかのぼることが できる。1880年以来の都市の発達は, 都市システムの 新規生成といらよりも, 既存の都市システムの再調整過 程であった。

1880 年以来の主要な変化は, 大都市集中の進行 と 太
平洋岸の縱貫線沿線諸都市の成長であった。1908年以 前には変化が比較的大きかったのに対して 1908 年以後 は安定的で，すでに成立しつつあった大都市・縦貫線優 位の傾向がさらに強まった。

1908 年以前の変動は 鉄道網の骨格形成期でもあった が，鉄道網の拡張と新規路線沿いの諸都市の成長との間 に明白な対応関係を空間的に見出すことは困難である。 むしろ鉄道網は大都市・縦貫線優位の傾向をさらに助長 したと言える。三大都市圏の成長の鈍化，広域中心都市 の成長, 高速道路・新幹線・航空の発達などを含めて最 近就よび近い将来の動向を考察する際にも，大都市・縦 貫線の定義の若干の拡張によって, 基本的な傾向は変わ らないと考えることがでさよう。 